\title{
EFEITOS DA REVOGAÇÃO DO TRATADO INTERNACIONAL POR ATO UNILATERAL DO PRESIDENTE DA REPÚBLICA
}

Marcelo Ribeiro do Val ${ }^{*}$

\section{Resumo}

Este trabalho é resultado de um estudo comparativo entre a teoria das liberdades públicas e a evolução da jurisprudência do Supremo Tribunal Federal, com base em um caso concreto sobre o tema: a Ação Direta de Inconstitucionalidade n ${ }^{\circ}$. 1.625/DF. Submetida à Corte Constitucional brasileira, esta decidirá acerca da legitimidade da revogação, no plano interno, por ato unilateral do Chefe do Poder Executivo, dos direitos sociais contidos na Convenção no . 158, da Organização Internacional do Trabalho, referente à dispensa arbitrária de trabalhadores. O problema envolve a competência do Presidente da República para revogar, no plano interno, norma jurídica que veicula direitos fundamentais aos indivíduos, mediante ato unilateral de vontade, considerado o princípio da legalidade disposto no inciso II do artigo $5^{\circ}$ da Constituição Federal. O tema, além de envolver regras de nacionalização e vigência de tratados no ordenamento jurídico brasileiro, diz respeito à teoria dos direitos fundamentais, garantidos pela Corte de San José da Costa Rica, ainda que o instrumento normativo não seja originário das Convenções Interamericanas de Direitos Humanos. Vislumbra-se, com isso, a possibilidade hipotética de condenação pelo referido Tribunal Internacional, pela ratificação do ato no âmbito do Supremo Tribunal Federal, caso haja denúncia do ocorrido, tendo em conta o princípio do esgotamento dos recursos internos.

Palavras-chave: Tratados internacionais internalizados. Denúncia no plano externo. Eficácia.

\section{Introdução}

O tema ora abordado, os efeitos na ordem jurídica interna quando um tratado internacional é denunciado pelo Brasil, refere-se a assunto que reabre a discussão acerca das implicações entre os planos normativos internacional e interno, ainda não completamente superadas e que, mais uma vez, desafiam solução pelos ministros do Supremo Tribunal Federal. $\mathrm{Na}$ Ação Direta de Inconstitucionalidade $n^{\circ}$. 1.625/DF, da relatoria do ministro Maurício Corrêa, questiona-se a higidez do Decreto $n^{\circ} .2 .100 / 96$, que internalizou a denúncia à Convenção $n^{\circ} .158$, da Organização Internacional do Trabalho.

\footnotetext{
* Marcelo Ribeiro do Val, Advogado da União, Assessor de Ministro do Supremo Tribunal Federal, mestrando do Programa de Mestrado em Direito do UniCEUB, área de concentração: Direito das Relações Internacionais.
} 
A questão reside no fato de o Supremo ter firmado posicionamento no sentido de caber, isoladamente, ao Presidente da República denunciar os tratados internacionais firmados pelo Brasil, ato que tem por efeito desobrigar a nação perante os demais Estados e Organismos Internacionais.

No caso, contudo, a exemplo do que ocorre em diversos tratados internacionais, a Convenção $n^{\circ} .158$ da OIT não constitui norma de direito internacional, cujo conteúdo se refere a uma obrigação contratual entre Estados soberanos ou sujeitos de Direito Internacional. Ela veicula regras gerais já incorporadas no ordenamento jurídico pátrio, após regular processo de internalização pelo Decreto $\mathrm{n}^{\circ} 1.855 / 96$, conferindo eficácia integral a dispositivo constitucional relativo a direito social que cuida da indenização trabalhista por dispensa arbitrária pelo empregador: o inciso I do artigo $7^{\circ}$ da Carta da República.

A proposta do presente trabalho, que não tem a pretensão de esgotar o tema, é discutir a questão, revelando as implicações internas trazidas ao crivo do Supremo na referida Ação Direta. Esse será o leading case da matéria e fixará entendimento sobre vigência independente ou não, no plano interno, de tratado internacional internalizado, que veicule direito substantivo, mediante ato revogatório unilateral do Presidente da República, considerado o inciso II do artigo $5^{\circ}$ da Constituição de 1988.

\section{A Constituição e o Supremo Tribunal Federal}

Acerca do instituto Tratado Internacional, a Carta Magna brasileira não o incluiu no rol do artigo 59, deixando, mais uma vez, a exemplo das Cartas anteriores, ao encargo da construção doutrinária e jurisprudencial a fixação dos parâmetros de validade e de eficácia quando incorporado no plano do ordenamento jurídico interno. Interpreta-se a omissão como eloqüente pelo fato de a Constituição atribuir competências próprias a cada um dos tipos normativos arrolados. Assim, ao excluí-los, facultou aos tratados internacionais veicular, no âmbito interno, matérias de qualquer natureza, observados os limites do $\S 4^{\circ}$ do artigo 60 da Carta Federal e os ritos de aprovação legislativa (para a proteção às minorias), daí a previsão do controle de constitucionalidade pelo Poder Judiciário. Esse entendimento foi, inicialmente, rechaçado pelo Supremo quando, ao julgar a ADI-MC n ${ }^{\circ}$. 1.480/DF, analisou o tratado sob óptica da constitucionalidade formal e decidiu, em sede precária, que ele não poderia atuar como sucedâneo de lei complementar para atender ao inciso I do artigo $7^{\circ}$ da Carta Constitucional, considerado o quorum qualificado de aprovação exigido. $\mathrm{Na}$ assentada, ficou vencido o ministro Carlos Velloso, que afastava o vício formal, entendendo haver recepção constitucional, tendo em conta o tipo normativo sem competência específica.

A ausência de disciplina expressa sobre os tratados internacionais lato sensu não impede, com efeito, que se extraia do texto constitucional a compreensão da sua natureza 
jurídica. De fato, ao prever nos parágrafos $2^{\circ}$ e $3^{\circ}$ do seu artigo $5^{\circ}$, a possibilidade de os tratados internacionais fixarem outros direitos e garantias aos cidadãos, a Constituição da República o tem como espécie de instrumento normativo, obedecido o quorum de aprovação legislativa.

O tratado internacional, na ordem externa, todavia, não tem como fonte normativa os poderes estatais internos, mas Estados soberanos e organismos internacionais. Figura, apenas, como instrumento normativo do Direito das Gentes, vinculando, num primeiro momento, apenas as partes contratantes, mediante procedimento que observa o ordenamento jurídico interno de cada sujeito de Direito Internacional.

No caso do Brasil, para entrar em vigor no plano internacional, o tratado internacional assinado pelo Presidente da República, na condição de Chefe de Estado, ou por delegação ñ inciso VIII do artigo 84 e inciso IV do artigo 87 da Carta Republicana ñ, necessita de referendo do Congresso Nacional para, depois, ser ratificado perante os demais contratantes, salvo no caso de autorização prévia do Parlamento.

No plano interno, por sua vez, o Supremo Tribunal Federal entendeu, no julgamento do $\mathrm{RE} \mathrm{n}^{\circ}$. 71.154/PR, que o tratado internacional passa a vigorar no plano interno a partir da publicação do decreto executivo que o promulga. Isso ocorre após o decreto de referendo do Parlamento e da ratificação no âmbito internacional.

Nesse precedente, também considerado o leading case da matéria, o Tribunal fixou o posicionamento de que, observada a tramitação acima, o tratado internacional passa a vigorar no ordenamento jurídico interno, independentemente de reprodução do seu texto em lei. Dispensou, portanto, a dupla manifestação do Congresso Nacional e reconheceu a imediata eficácia interna, inclusive naquilo que modificar a legislação interna anterior. Convém frisar que, embora o julgamento tenha ocorrido sob a égide da Emenda Constitucional $n^{\circ}$. 1/1969, o eminente relator lembrou que o processo de internalização do tratado era idêntico em todos os textos constitucionais, desde a Carta de 1946. Foi mantida, também, a competência do Chefe de Estado no inciso VIII do artigo 84 da Constituição de 1988.

A seguir, noutra oportunidade, o Supremo enfrentou nova questão jurídica envolvendo a vigência e a hierarquia entre tratado internacional e lei interna. No Recurso Extraordinário $n^{\circ}$. 80.004/SE, o Tribunal reconheceu a validade do Decreto-lei ${ }^{\circ}$. 427/1969, que alterou, parcialmente, no âmbito doméstico, a Lei Uniforme das Notas Promissórias, cuja fonte é a Convenção de Genebra sobre letras de câmbio e notas promissórias, tratando-a, no âmbito interno, como lei nacional.

Do julgamento destaca-se, inicialmente, o posicionamento do ministro Xavier de Albuquerque, relator originário. Ele, embora vencido no mérito, baseou-se em precedentes do Supremo, tanto no RE $\mathrm{n}^{\circ}$. 71.154/PR quanto em acórdãos relatados pelos ministros Philadelpho 
Azevedo, Orozimbo Nonato e Laudo de Camargo, para consignar a irrevogabilidade das normas de direito internacional pelas leis ordinárias brasileiras, consideradas as distinções das espécies normativas e a unidade do tratado, salvo o permissivo contido no próprio tratado ou no caso de denúncia. Daí, declarou, pela via incidental, a inconstitucionalidade do Decreto-lei $\mathrm{n}^{\circ}$. 427/1969.

Após, seguiu-se o voto do ministro Cunha Peixoto, que, abrindo divergência, consignou a existência das teorias monista e dualista para situar o ordenamento jurídico brasileiro nesta segunda. Com isso, apontou que a Carta então em vigor não incluía os tratados entre as leis positivas brasileiras. Sustentou, ainda, que, mesmo com a ratificação e a promulgação pelo Presidente da República, após o referendo do Parlamento, o tratado internacional somente obrigaria o Estado brasileiro perante os demais contratantes, sem qualquer vigência na ordem interna. Tal seria possível somente com a aprovação de uma lei nacional, tendo em conta a diversidade de fontes e o processo de formação dos instrumentos normativos internos. Por essa razão, negou vigência ao tratado e manteve a do Decreto-lei impugnado.

Cabe destacar duas passagens do voto do ministro Cunha Peixoto que revelam questões da maior importância, ainda hoje não superadas. Na primeira, rebate a tese daquele que o precedeu, dizendo ser inaceitável, sob pena de inconstitucionalidade, o tratado revogar lei interna, pois, em última análise, seria o mesmo que atribuir ao Chefe do Executivo o poder de revogar norma com força de lei, mediante simples denúncia, ou seja, mero ato de vontade, sem a participação política do Parlamento. Na segunda, afirma que o artigo 98 do Código Tributário Nacional, sob pena de inconstitucionalidade, só poderia referir-se a tratados e convenções internacionais que dispusessem sobre matéria contratual, firmados por governantes sobre assuntos tributários. Daí, entendeu que a norma que pactua, a exemplo das leis de isenção tributária por prazo determinado, constitui título de direito subjetivo, não podendo ser revogada por norma geral.

Assim, embora num primeiro momento, a posição do eminente ministro possa parecer um retrocesso para o direito internacional, na verdade, as deficiências apontadas eram pertinentes e peculiares, revelando que o estudo dos tratados ainda se encontrava inacabado.

Prosseguindo o julgamento, o voto do ministro Cordeiro Guerra enriqueceu ainda mais os debates. Para o eminente magistrado, ao contrário do seu antecessor, a Corte Constitucional, no julgamento do $\mathrm{RE} \mathrm{n}^{\circ}$. 71.154/PR, pusera termo à controvérsia a respeito da vigência, no plano interno, dos tratados que cumprem o rito para a incorporação.

O magistrado reconheceu a primazia do direito internacional sobre o direito interno, dada a dimensão do compromisso, daí a possibilidade deste ser revogado por aquele. Contudo, embora entendesse que o inverso não fosse possível, pois não implicaria denúncia no âmbito externo, afirmou que os Poderes da República estavam vinculados à lei interna. Concluiu, então, 
que a lei ordinária não revogaria a aplicação de tratado vigente que versasse sobre o mesmo tema de forma diversa, e, sim, o excepcionaria. Isso porque não há autorização constitucional para o Poder Judiciário declarar a invalidade de uma lei ordinária posterior, que disponha sobre matéria de sua competência.

De acordo com o eminente ministro, havendo a revogação da lei que o excepciona, o tratado voltaria a produzir efeitos jurídicos internos. Já no âmbito externo, de forma totalmente independente, o tratado não deixaria de viger, considerados os pressupostos de validade, a distinção de fontes e os destinatários de seus mandamentos, levando-o, assim, a admitir a sua violação no plano internacional. Com isso, considerou válida a lei brasileira.

No voto, destacam-se, também, duas importantes conclusões: a) a denúncia do tratado no plano internacional não implicaria derrogação da norma no âmbito interno, necessitando, para isso, de lei posterior; e (b) o artigo 98 do CTN seria aplicável somente aos acordos contratuais de tarifas vigentes, não a todo e qualquer tratado.

O voto do quarto ministro, Leitão de Abreu, adere à tese da não aplicação direta dos tratados internacionais no direito nacional, mas afasta a necessidade da dupla submissão ao Parlamento, admitindo o referendo e a promulgação como atos satisfatórios para lhes atribuir validade e vigência com força de lei, após ratificados.

Segundo o magistrado, não se poderia falar em hierarquia ou revogação entre tratado internacional e lei interna quando a Constituição assim não o diz. Além disso, seriam de instrumentos normativos diversos, com formas e foros próprios para revogação, como a denúncia. Ocorre que, não sendo lícito aos tribunais deixar de aplicar lei posterior e incompatível ao tratado, primou-se pela suspensão da aplicabilidade deste até que aquela fosse revogada.

$\mathrm{Na}$ assentada, o ministro Rodrigues Alckmin também se posicionou no sentido de validar a lei brasileira em face da norma internacional anterior. Destacou que, além de não conferir hierarquia, a Carta Maior não condicionava a disposição de matéria doméstica à prévia necessidade da denúncia de tratado que dispusesse sobre o mesmo tema.

Deve-se registrar, contudo, a parte da fundamentação em que o magistrado afasta a alegada violação ao princípio do ato contrário, entendendo que a perda dos efeitos dos tratados não está condicionada à ab-rogação regular, por meio de procedimento correspondente ao de sua formação. A tese implicaria admitir, da mesma forma, a superioridade, no âmbito interno, das leis anteriores sobre os tratados ulteriores, e a vedação, no plano externo, à denúncia isolada por um Estado signatário.

Destacados os trechos mais importantes do acórdão para o presente estudo, nota-se que os mais variados entendimentos expostos pelo Supremo Tribunal Federal, somados ao fato de as Constituições brasileiras serem sempre omissas quanto ao papel dos tratados internacionais 
dentro da ordem jurídica brasileira, denotam que o instrumento normativo se encontra, ainda, inacabado pela ciência do direito no âmbito nacional. Por outro lado, constata-se que esta Corte vem lapidando o instituto, ainda que com certa parcimônia, talvez ciente de que todas as correntes possuem consistência científica, mas nenhuma, ainda, foi capaz de esgotar o tema de modo a satisfazer as vertentes interna e externa. De toda forma, apenas um ministro não reconheceu a força normativa interna do tratado.

Promulgada a Constituição de 1988, a situação repetiu-se, não por omissão do constituinte, mas pelo estágio de evolução do instituto do tratado no Brasil.

O certo é que, mais uma vez, o Supremo foi provocado a se pronunciar sobre o tema da vigência de tratado no ordenamento interno, agora na ADI $n^{\circ}$. 1.625/DF, da relatoria do ministro Maurício Corrêa, cujo julgamento, já iniciado, interrompeu-se pelo pedido de vista do ministro Joaquim Barbosa.

Questionada a revogação, pelo Presidente da República, do decreto executivo que editou a Convenção $n^{\circ}$. 158, da OIT, devido ao fato de a norma já ter sido incorporada no ordenamento jurídico interno, mediante referendo do Parlamento, o cerne é saber se, no plano interno, a norma é passível de revogação por ato unilateral do Poder Executivo.

O relator, em consistente voto, atribui caráter normativo ao ato derrogatório do tratado já incorporado, daí conhece da ação, citando, como precedente, a ADI-MC nº 769 .

Ao enfrentar o mérito, o relator repete o entendimento assentado pela Corte no sentido de que, para ser recepcionado pelo ordenamento jurídico interno, o tratado necessita da soma das manifestações de vontade convergentes do Congresso Nacional e do Presidente da República, que o ratifica no âmbito internacional e o promulga no plano interno. Formalizada a recepção, o tratado situa-se no mesmo plano normativo das leis ordinárias, daí o conflito aparente de normas ser resolvido pela aplicação dos critérios da ordem cronológica e da especialidade.

Assim, somando as premissas (a) de que o tratado possui força, inclusive derrogatória, de lei; (b) que a Carta de 1988 atribui ao Congresso Nacional o poder de resolver, definitivamente, sobre a sua incorporação; e (c) que norma derrogatória de lei tem a mesma força normativa, chega-se à conclusão de que o ato isolado de denúncia do Presidente da República vale apenas no âmbito internacional. Para que valha no plano interno, considerada a independência das esferas políticas, é necessário que se tenha o aval ou referendo do Parlamento, que representa o povo, sob pena de, em ultima análise, atribuir-se ao Chefe do Executivo o poder de revogar lei mediante ato unilateral.

Por outro lado, seguindo o posicionamento estabelecido pelo Tribunal, não se pode afirmar que o decreto presidencial que revogou a promulgação do tratado seja inconstitucional, eis que exercido pela autoridade no âmbito de sua competência. Diante dos fundamentos 
apresentados, entendeu o ministro Maurício Corrêa, possivelmente inspirado no instrumento da medida provisória, votar, pela procedência em parte, a ação direta, para dar interpretação conforme o artigo 49, inciso I, da Carta Constitucional, no sentido de condicionar a validade dos efeitos do ato ao referendo do Parlamento. Após, o ministro Carlos Britto o acompanhou, e o ministro Joaquim Barbosa pediu vista do processo.

\section{A problemática do tema}

Diante dos parâmetros ora colocados, passa-se à verificação dos efeitos jurídicos no ordenamento pátrio quando um tratado internacional é denunciado. Para melhor encaminhar as discussões, propõe-se o seguinte problema: a revogação de tratado internacional por ato unilateral do Presidente da República tem o condão de revogar a norma no plano do ordenamento jurídico interno?

Recorda Pedro Dallari que os tratados internacionais possuem três momentos de vigência distintos: (a) a vigência no plano internacional, resultado do atendimento aos requisitos previstos no seu corpo; (b) a vigência do tratado para o Brasil, que ocorre com o ato de ratificação ou adesão e inicia com a formalização da vontade ou com o decurso de prazo, contado a partir da formalização, se previsto no acordo; e, (c) vigência do tratado na ordem jurídica brasileira, que tem como pressuposto as duas vigências anteriores. É o que ocorre com o decreto de promulgação do Presidente da República, somente publicado após o referendo do Congresso e a ratificação ou adesão no plano internacional.

Dentre os atos que marcam a vigência, importa caracterizar a natureza do decreto de promulgação do Chefe do Poder Executivo. O professor Francisco Rezek (2005) preleciona o tema:

[...] no Brasil, se promulgam por decreto do Presidente da República todos os tratados que tenham feito por objeto de aprovação congressional antes da ratificação ou adesão. Publicam-se apenas, no Diário Oficial da União, os que hajam prescindido do assentimento parlamentar e da intervenção confirmatória do chefe de Estado. No primeiro caso, o decreto de promulgação não constitui reclamo constitucional: ele é produto de uma praxe tão antiga quanto a Independência e os primeiros exercícios convencionais do Império. Cuida-se de um decreto, unicamente porque os atos do chefe de Estado costumam ter esse nome. Por nada mais. Vale como ato de publicidade da existência do tratado, norma jurídica de vigência atual ou iminente. Publica-os, pois, o órgão oficial, para que o tratado - cujo texto completo vai em anexo - se introduza na ordem legal, e opere desde o momento próprio. A simples publicação no Diário Oficial, autorizada pelo ministro das Relações Exteriores e efetivada pela Divisão de Atos Internacionais do Itamaraty, garante a introdução no ordenamento jurídico nacional dos acordos celebrados no molde "executivo" - sem a manifestação tópica do Congresso ou intervenção formal, a qualquer título, do Presidente da República. 
Pedro Dallari entende que o decreto de promulgação é o ato de publicação exigido para obrigar os súditos. Revela, ainda, que Antonio Cachapuz de Medeiros concebe ao decreto de promulgação a natureza de lei em sentido amplo, à qual se impõe a publicação por determinação do Chefe do Poder Executivo, nos termos do artigo 84, inciso IV, da Constituição Federal, levando em conta o princípio da legalidade. Destaca, também, que Alberto Xavier, ao analisar o impacto dos tratados internacionais em matéria tributária, considera, no entanto, que se é certo que tratado não publicado não é oponível aos particulares, no sentido de lhes exigir obrigações, a verdade é que estes podem invocá-los para exigir direitos que dele decorram.

De fato, reconhecida nos tratados a força de lei nacional, desde que completado o processo de formação nos planos externo e interno, impõe-se a conclusão de ser o decreto de promulgação o último ato do processo legislativo necessário para dar ciência, vigência e para obrigar os súditos, ou seja, equivale à sanção de lei.

A promulgação é, portanto, apenas a última fase de um ato complexo, próprio do processo legislativo. Tanto é assim que o Chefe da Nação pode, apesar de referendado pelo Congresso, deixar de promulgá-lo e denunciá-lo para que a norma nunca vigore no ordenamento interno. Por outro lado, uma vez promulgado, cria-se uma norma interna que obriga o indivíduo, na forma do inciso II do artigo $5^{\circ}$ da Carta Federal, e, até mesmo, o Presidente da República e o Parlamento. Portanto, trata-se de ato processual legislativo que constrói a norma como produto acabado, resultado da vontade do país, segundo José Afonso da Silva, em solucionar conflito de interesses sociais por decisões de maioria parlamentar.

Situada a natureza jurídica do decreto de promulgação, retornamos à questão posta: após a publicação, pode outro decreto presidencial revogá-lo?

\section{Denúncia e efeitos}

A primeira notícia de trabalho jurídico sobre a denúncia do tratado vem de Clovis Beviláqua, que emitiu um célebre parecer em 5/7/1926, para fixar a idéia, quando atuava no Ministério das Relações Exteriores. Trata-se do caso em que o Brasil, discordando do posicionamento que culminou na perda da cadeira no Conselho de Segurança de representante da América Latina, por ato unilateral do Chefe de Estado, denunciou o Pacto da Sociedade das Nações sem prévia aprovação pelo Parlamento, sob o argumento de autorização implícita deste Poder na cláusula geral de denúncia. $\mathrm{O}$ argumento foi que, autorizado pelo Parlamento a firmar sozinho o tratado, o mesmo poder existia para a denúncia.

Francisco Rezek, por seu turno, entende que o tratado decorre da comunhão de esforços do Governo com o Parlamento. Basta, portanto, a vontade de um dos Poderes para desobrigar o país e denunciá-lo, seja no plano externo como no interno. 
Uma terceira teoria vem do direito comparado, do caso Barry Goldwater, quando o Presidente Carter, buscando, nos anos 70, aproximar o Estado norte-americano com a China comunista, denunciou o tratado de defesa mútua firmado entre os Estados Unidos e Taiwan. Questionou-se o ato com fundamento na violação do Princípio do Ato Contrário, alegando-se que o tratado, para ser desfeito, necessitaria percorrer o mesmo caminho da internalização. No caso norte-americano, dependeria da soma das vontades do Presidente com dois terços do Senado. A Suprema Corte, porém, não conheceu o pedido, entendendo tratar-se de questão política.

No voto proferido no mencionado RE $\mathrm{n}^{\circ}$. 80.004/SE, o ministro Cunha Peixoto, como se viu, entende ser inaceitável que a denúncia de um tratado por ato do Presidente da República possa revogar uma norma interna com força de lei. Daí, porque passa a defender a necessidade de aprovação de lei interna idêntica ao tratado. A Corte, no julgamento, não resolveu se a lei revogaria ou excepcionaria o tratado no plano interno, confirmando apenas a validade e a eficácia da norma nacional posterior.

Ocorre que o Supremo Tribunal Federal, ao enfrentar novamente a questão da prisão civil do depositário infiel no RE $n^{\circ}$. 66.343/SP, embora não terminado o julgamento, sinalizou, pela maioria já formada, que modificará o posicionamento atual para dar nova interpretação ao parágrafo $1^{\circ}$ do artigo $5^{\circ}$ da Carta Maior, notadamente mais alinhada com a política de direito internacional. Destaque-se o voto do ministro Gilmar Mendes que, restaurando o posicionamento de Cordeiro Guerra, assim manifestou-se:

É preciso ponderar, no entanto, se, no contexto atual, em que se pode observar a abertura cada vez maior do Estado constitucional a ordens jurídicas supranacionais de proteção de direitos humanos, essa jurisprudência [paridade entre tratado e lei ordinária] não teria se tornado completamente defasada. Não se pode perder de vista que, hoje, vivemos em um "Estado Constitucional Cooperativo", identificado pelo Professor Peter Häberle como aquele que não mais se apresenta como um Estado Constitucional voltado para si mesmo, mas que se disponibiliza como referência para os outros Estados Constitucionais membros de uma comunidade, e no qual ganha relevo o papel dos direitos humanos e fundamentais [...]Portanto, diante do inequívoco caráter especial dos tratados internacionais que cuidam da proteção dos direitos humanos, não é difícil entender que a sua internalização no ordenamento jurídico, por meio do procedimento de ratificação previsto na Constituição, tem o condão de paralisar a eficácia jurídica de toda e qualquer disciplina normativa infraconstitucional com ela conflitante.

Nesse sentido, é possível concluir que, diante da supremacia da Constituição sobre os atos normativos internacionais, a previsão constitucional da prisão civil do depositário infiel (art. $5^{\circ}$, inciso LXVII) não foi revogada pela ratificação do Pacto Internacional dos Direitos Civis e Políticos (art. 11) e da Convenção Americana sobre Direitos Humanos - Pacto de San José da Costa Rica (art. $7^{\circ}, 7$ ), mas deixou de ter aplicabilidade diante do efeito paralisante desses tratados em relação à legislação infraconstitucional que disciplina a matéria, incluídos o art. 1.287 do Código Civil de 1916 e o Decreto-Lei n ${ }^{\circ} 911$, de $1^{\circ}$ de outubro de 1969. 
Nada obstante limitar a aplicação do precedente aos direitos humanos, chamamos atenção para a incidência sobre direitos e obrigações em relação aos indivíduos. De toda forma, se, para o Supremo, o direito humano, como o direito social em exame, possui supremacia sobre a lei nacional, por ela não poder ser revogada, o que dirá um mero ato executivo? Para George Galindo, trata-se, inclusive, de direito materialmente constitucional, daí ser irrevogável.

Dentre as matérias atualmente veiculadas nos tratados, além das manifestações de alianças e dos reconhecimentos de nação soberana, que geralmente não obrigam; dos acordos de extradição e de comércio, que obrigam os Estados signatários; e dos acordos institucionais, responsáveis por criar organismos internacionais; há ainda os acordos que estipulam regras uniformes de condutas a serem adotadas pelos contratantes e que criam relações jurídicas entre os Estados e súditos, seus e de outros Estados, e entre súditos. Todas essas matérias devem observar, no plano da validade, cada qual, o permissivo constitucional vigente em cada Estado.

No tocante à vigência, conforme a matéria versada, o tratado pode ou não ter dupla vertente, ou seja, pode depender, apenas, da assinatura no plano internacional, quando a matéria em nada interfere no âmbito doméstico, como um protocolo de intenções, ou pender de incorporação no ordenamento jurídico interno.

Embora o professor Francisco Rezek alerte sobre o desprestígio de que vem padecendo a classificação Rousseau de tratados contratuais e tratados normativos, é certo que, em termos de eficácia, ao menos no âmbito interno, a distinção é útil, notadamente na avaliação do Supremo, quando interpretou o artigo 98 do CTN à luz do texto constitucional. Esse atribuiu intangibilidade aos tratados que versem títulos jurídicos subjetivos em matéria tributária.

No âmbito desse estudo, temos o reconhecimento precário, pelo Supremo, do possível vício formal da Convenção $\mathrm{n}^{\circ}$. 158 da OIT, que dispõe sobre condições à dispensa arbitrária de empregados, pois o inciso I do artigo $7^{\circ}$ da Carta Política outorgou competência da matéria à lei complementar para regulamentá-la.

Os precedentes do Supremo demonstram que o problema da formação, vigência e revogação dos tratados ocorre, justamente, quando esses produzem eficácia no plano interno, como nos casos da Convenção de Genebra sobre títulos de crédito, acordos tarifários do GATT, Convenção Interamericana de Direitos Humanos e Convenção no. 158 da OIT. Em outras palavras, os problemas surgem quando a eficácia da norma obriga, outorgando direitos e deveres aos indivíduos ou onerando o patrimônio nacional.

Baseado nessas premissas, conclui-se que, possuindo o tratado vigência independente nos planos interno e externo, pode, em tese, ser denunciado ou revogado em um dos planos, sem comprometer a existência, validade ou eficácia no outro, embora possa configurar ilícito no âmbito internacional. Além disso, os tratados que não veiculam obrigações 
ou normatizam condutas dos cidadãos, ou ainda, não oneram o patrimônio público, dispensam o referendo do Congresso para serem denunciados, isoladamente, pelo Chefe de Estado, (inciso I do artigo 49 da Carta de 1988).

Relativo aos tratados, vigentes ou não no plano internacional, que a Constituição Federal, ante a matéria versada, exige o referendo do Congresso para vigorar no ordenamento jurídico nacional, a nosso ver o tratamento deve ser diverso.

Vigorando, no Brasil, o Estado Democrático de Direito, prevalece o princípio da soberania popular. Esse princípio é legitimador dos atos de Estado, só revelado mediante a expressão da vontade do povo, respeitado o direito das minorias representadas no Congresso Nacional.

Nesse caso, se a revogação da norma retira direito sacramentado pela vontade popular, o ato deve ter a concordância do povo por meio de seus representantes. Não se trata, aqui, de evocar o princípio do ato contrário, mas de revogar um instrumento normativo concebido como lei, do princípio fundamental da legalidade, contida no artigo $5^{\circ}$, inciso II, combinado com o inciso VIII do artigo 49 da Constituição da República.

No caso enfrentado pelo Supremo na ADI n ${ }^{\circ}$. 1.625/DF, identifica-se um pressuposto de ordem prática, que é tomado como insuperável, relativo à sua competência para conhecer da ação e analisar a constitucionalidade do tratado, inclusive pela via do controle abstrato. Trata-se da combinação dos incisos I, alínea "a", e III, alínea "b” do artigo 102 da Carta Federal.

Com base no pressuposto de que o conhecimento da ação direta depende da qualidade da norma como lei em sentido material, ou seja, tenha aplicação geral e abstrata, caso bastasse apenas a vontade unilateral de um dos Poderes - Legislativo ou Executivo - para denunciar o tratado no plano internacional, revogando-o no plano interno, estar-se-ia a admitir a comunicação de instâncias normativas, própria da teoria monista. Essa idéia é contraposta à necessidade do processo legislativo de internalização e à impossibilidade do controle de regularidade, pelo Supremo, no plano internacional.

Por outro lado, permitir a revogação, no plano interno, mediante ato unilateral do Presidente da República, seria admiti-lo senhor das regras de obrigação e de disposição do patrimônio público. Essa idéia contrapõe-se à impossibilidade da figura do decreto executivo autônomo, pois o tratado, segundo o Supremo, revoga (ou suspende) lei anterior, sendo o inverso também possível.

Ilustramos a possibilidade de outro desdobramento na esfera internacional, caso o Supremo Tribunal Federal julgue pela constitucionalidade do decreto: o ato que revogou direitos sociais protegidos pela Corte Interamericana de Direitos Humanos. Daí, o Brasil poderá ser processado e condenado por desrespeito ao princípio da legalidade, direito fundamental previsto 
na alínea "d" do artigo $7^{\circ}$ do Protocolo Adicional à Convenção Americana sobre Direitos Humanos em matéria de Direitos Econômicos, Sociais e Culturais (Protocolo de San Salvador). Eis o teor do preceito:

Art. $7^{\circ}$ - Os Estados-partes neste Protocolo reconhecem o direito ao trabalho, a que se refere o artigo anterior, pressupõe que toda pessoa goze dele em condições justas, eqüitativas e satisfatórias, para o que esses Estados garantirão em suas legislações, de maneira particular: [...]

d) Estabilidade dos trabalhadores em seus empregos, de acordo com as características das indústrias e profissões e com as causas de justa separação. Nos casos de demissão injustificada, o trabalhador terá direito a uma indenização ou à readmissão no emprego ou a quaisquer outras prestações previstas pela legislação nacional.

Assim, nada obstante a Convenção $\mathrm{n}^{\mathrm{o}}$. 158 da OIT não integrar o rol de pactos firmados no âmbito do sistema de proteção americano de Direitos Humanos, a positivação interna a integrou, desde a internalização, no rol dos direitos protegidos. Daí, a possibilidade de o Brasil ser condenado pela Corte de San José, não apenas pelo ato do Presidente da República, mas também pela decisão do Supremo Tribunal Federal, caso declare a constitucionalidade do ato executivo.

\section{Conclusão}

A norma versada no tratado - mero veículo normativo - vigora independentemente da vontade dos poderes constituídos, que a submetem, porquanto estejam abaixo de sua autoridade. As esferas de existência, validade e eficácia dos tratados aperfeiçoados não mais se comunicam, de modo que a denúncia não revoga a norma no plano interno.

Tal qual a medida provisória, a lei complementar ou a lei ordinária, o tratado vigora como um produto do debate democrático entre maiorias e minorias, por isso, não é facultado ao Presidente da República revogar o ato de sanção da norma ou a edição de uma medida provisória convertida no Congresso.

Diante disso, não se desconhece o posicionamento do eminente professor Francisco Rezek, para quem é possível extinguir a vigência de qualquer tratado internacional por ato unilateral do Chefe da Nação ou do Congresso Nacional (salvo nos casos de exorbitação de poder). Concorda-se, contudo, apenas parcialmente, com a idéia, exatamente no que diz respeito aos tratados que fixam relações meramente políticas entre Estados signatários.

A regra, entende-se, não se aplica no âmbito interno, quando o tratado veicula normas que, segundo a nossa Ordem Constitucional, reclama forma de lei, pois, nas matérias em que vigora o princípio da legalidade, não se aplica, no âmbito interno, a primazia da vontade de um dos Poderes da República. Faz-se necessário, como em qualquer instrumento normativo 
integrante do plano da legalidade - artigos $5^{\circ}$, inciso II e 59 da Carta Constitucional -, que a revogação da norma, no plano interno, passe pelo crivo democrático dos dois Poderes políticos. Dessa forma, é declarada inconstitucional, com aviso ao Senado - artigo 52, inciso X, do Diploma de 1988 -, sob pena de configurar ofensa ao direito de minorias, conforme acentuado por José A. da Silva e pelo ministro Cunha Peixoto. A forma como foi feita tem contornos de norma de exceção.

Tendo em conta as peculiaridades da formação e da revogação dos tratados, inclusive quanto à independência de planos e às etapas a serem ultrapassadas, prima-se pela possibilidade da extinção da vigência do tratado, no plano interno, mas condicionando a eficácia do decreto ao referendo do Parlamento, aplicando-se a norma até então, desde que haja outra lei regulamentando o dispositivo constitucional, que não pode ter retrocedida a força normativa, uma vez em plena eficácia.

Em suma, conclui-se o breve trabalho expondo o tema ao debate, mas aderindo ao entendimento fixado pelo ministro Maurício Correa, relator da Ação Direta de Inconstitucionalidade $n^{\circ} .1 .625 / \mathrm{DF}$, embora sob outros fundamentos.

No tocante à esfera internacional, entende-se que, caso não sobrevenha uma outra lei regulamentando a mesma matéria antes de o Parlamento ratificar o decreto presidencial revogatório, haverá, como efeito externo, a situação de ilícito a Direitos Humanos, com participação do Supremo Tribunal Federal, passível de condenação pela Corte de San José da Costa Rica.

\section{Abstract}

We proudly present this work, which is the result of a comparative study of the public liberties theory and the evolution of the Brazilian Supreme Court jurisprudence, based on a specific precedent: the Direct Action of Unconstitutionality n ${ }^{\circ}$. 1.625/DF (ADI n ${ }^{\circ}$. 1625/DF). By hearing the cause, the Court will decide whether is legitimate to revoke, under Brazilian law, by means of a unilateral act of the Chief of the Executive Branch, the social rights set forth in the International Labor Organization Convention $n^{\circ} .158$, which deals with arbitrary dismissal of workers. The problem refers to determine whether, under the Brazilian legal system, the President has the power to revoke a law that establishes individuals' fundamental rights, by a unilateral act of will, taking into consideration the legality principle set forth on item II of article 5 of the Brazilian Constitution ${ }^{\circ}$. The theme not only deals with the rules regarding the incorporation of international treaties in Brazil, but also with the fundamental rights theory, guaranteed by the San Jose of Costa Rica Inter-American Court, even if the legal norm does not derive from the Inter-American Convention of Human Rights. One may foresee a hypothetical condemnation by 
the Court, if the Brazilian Supreme Court confirms the President's decision, taking into account the exhaustion of local remedies principle.

Keywords: Internalized international treaties. Revocation by a unilateral act of the executive branch. Effectiveness.

\section{Referências}

AMARAL JÚNIOR, José Levi Mello do. Reforma define status jurídico de tratados sobre direitos humanos. Disponível em: <http://conjur.estadao.com.br/static/text/32582,1>.

. Reforma sepulta chance de status constitucional automático a tratadas. Disponpível em: <http://conjur.estadao.com.br/static/text/32704,1>.

BIDART CAMPOS, Gérman J. Teoría general de los derechos humanos. Buenos Aires: Astrea; 1991.

BONAVIDES, Paulo. Curso de direito constitucional. 7. ed. São Paulo: Malheiros, 1997.

BRASIL. Decreto $n^{o}$. 2.100, de 20 de dezembro de 1996. O Presidente da República torna público que deixará de vigorar para o Brasil, a partir de 20 de novembro de 1997, a Convenção da OIT $n^{\circ}$. 158, relativa ao Término da Relação de Trabalho por Iniciativa do Empregador, adotada em Genebra, em 22 de junho de 1982, visto haver sido denunciada por nota do governo brasileiro à Organização Internacional do Trabalho, tendo sido a denúncia registrada, por esta última, a 20 de novembro de 1996. Disponível em: $<$ http://www.stf.gov.br/portal/peticaoInicial/ verPeticaoInicial.asp?base $=$ ADIN\&s $1=1625 \&$ processo=1625 $>$ Acesso em $: 16$ out. 2007.

BRASIL. $n^{\circ}$ 1480. Ação Direta de Inconstitucionalidade. Relator: Min. Celso de Mello. Diário da Justiça, Brasília,DF, 18 maio 2001.

. Medida cautelar no 1.480, de 4 de setembro de 1997. Dispõe sobre a Ação Direta de Inconstitucionalidade. Relator: Min. Celso de Mello. Diário da Justiça, Brasília, DF, 18 maio 2001.

. Medida cautelar n. 769. Dispõe sobre a Ação Direta de Inconstitucionalidade. Relator: Min. Celso de Mello. Diário da Justiça, Brasília, DF, 8 abr. 1994.

. Medida cautelar $n^{\circ} 1.435$. Dispõe sobre a Ação Direta de Inconstitucionalidade. Relator: Min. Francisco Rezek. Diário da Justiça, Brasília, DF, 6 ago. 1999.

. Recurso extraordinário nº 66.343. Relator: Min. Cézar Peluso. São Paulo, SP.

. Recurso extraordinário $\mathrm{n}^{\circ}$. 71.154/PR, Relator: Min. Oswaldo Trigueiro. Diário da Justiça, Brasília,DF, 25 ago. 1971.

. Recurso extraordinário $n^{\circ}$. 80.004. Relator Min. Cunha Peixoto. Diário da Justiça, Brasília,DF, 29 dez. 1977. 
. Supremo Tribunal Federal. Disponível em: $<$ http://www.stf.gov.br/jurisprudencia/nova/ jurisp.asp> Acesso em: 12 ago. 2007.

CANOTILHO, J. J. Gomes. Direito constitucional. Coimbra: Almedina, 2003.

COSTA RICA. Corte Interamericana de Direitos Humanos. Disponível em: <http://www. corteidh.or.cr>. Acesso em: 29.jul..2007.

DALLARI. Pedro B. A. Constituição e tratados internacionais. São Paulo: Saraiva, 2003.

FERREIRA FILHO, Manoel G. Direitos humanos fundamentais. 8. ed. São Paulo: Saraiva, 2006.

GALINDO, George Rodrigo Bandeira. Tratados internacionais de direitos humanos e constituição brasileira. Belo Horizonte: Del Rey, 2002.

HESSE, Konrad. A força normativa da constituição. Tradução Gilmar Ferreira Mendes. Porto Alegre: Sergio Fabris, 1997.

KELSEN, Hans. Il problema della sovranità e la teoria del diritto internazionale. Tradução Agostino Carrino. Milano: Giuffrè, 1989.

. A essência e o valor da democracia. In: A DEMOCRACIA. São Paulo: Martins Fontes,

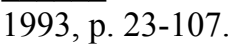
2003.

. A jurisdição constitucional. In: Jurisdição constitucional. São Paulo: Martins Fontes,

LIMA JÚNIOR, Jayme Benvenuto (Org.). Manual de direitos humanos internacionais: acesso aos sistemas global e regional de proteção dos direitos humanos. São Paulo: Loyola, 2002.

MELLO. Celso Antônio B. Curso direito administrativo. 13. ed. São Paulo: Malheiros, 2001.

MONTESQUIEU. Do espírito das leis. Tradução Jean Melville. São Paulo: Martin Claret, 2006.

REZEK, José Francisco. Direito internacional público. São Paulo: Saraiva, 2005.

SARLET, Ingo Wolfgang. A eficácia dos direitos fundamentais. 2. ed. Porto Alegre: Livraria do Advogado, 2001.

SILVA, José Afonso. Processo constitucional da formação das leis. 2. ed. São Paulo: Malheiros, 2007.

TAVOllaro, Agostinho T.; VELloso, Carlos Mário et al. (Coord.) In: Princípios constitucionais fundamentais: tratados internacionais, legislações nacionais e a emenda constitucional no. 45. São Paulo: Lex, 2005. 
TRINDADE, Antônio Augusto Cançado. A proteção internacional dos direitos humanos e o Brasil. 2. ed. Brasília: UnB, 2000.

TRINDADE, A. A. C. Tratado de direito internacional dos direitos humanos. 2. ed. Porto Alegre: Sergio Antonio Fabris, 2003. 2 v.

. A proteção internacional dos direitos humanos e o Brasil. 2. ed.. Brasília: UnB, 2000.

. O esgotamento de recursos internos no direito internacional. 2. ed. Brasília: UnB,1997.

. Tratado de direito internacional dos direitos humanos. 2. ed. Porto Alegre: Sergio Antonio Fabris, 2003. 